\title{
ASSESSMENT OF LITHUANIAN RURAL HOMESTEADS' WEBSITES QUALITY
}

\author{
Viktorija Grigaliūnaitė, Lina Pilelienė \\ Vytautas Magnus University, Lithuania \\ viktorija.grigaliunaite@vdu.lt; lina.pileliene@vdu.lt
}

\begin{abstract}
Considering tourism as a driving force in the growth of rural economy, the research in this industry is gaining its popularity. In the era of the Internet, no business is imaginable without having its own website. However, implementing a website does not already mean that customers will like and approve it. Website quality is a necessary task to maintain in line with its functioning. The aim of the research is to assess the quality of the Lithuanian rural tourism homestead websites. Only understanding the website-related factors that are important for consumers may lead to a proper management of a website and customer attraction as well. The research results show that the information on the websites has to be easy findable, clear, and consistent; photos that substantiate the information are necessary; the information and photos have to be managed properly; and the eWOM part has to be included on the website. Proper management of latter factors can enhance the possibility of maintaining a high quality website that encourages consumer intention to visit the homestead.
\end{abstract}

Key words: Lithuania, rural homesteads, rural tourism, website, website quality.

\section{Introduction}

The concept of 'rural tourism' has become allinclusive over the time (Patil \& Mulani, 2017); according to Ghadban et al. (2017) it encompasses many forms of tourism, such as nature-based tourism, community-based tourism, ecotourism, agro-tourism, and many more. Rural tourism is rapidly expanding all over the world (Hidalgo-Alcázar, Sicilia, \& De Maya, 2015). For communities living in rural areas, tourism is an important tool of revenue generation (Ghadban et al., 2017): tourism may provide jobs as well as generate additional income through the number of other allied activities (Patil \& Mulani, 2017); moreover, tourism development has a multiple social and cultural impact on the community (Csaholczi et al., 2017). Therefore, bearing in mind that the development of rural regions is one of the key targets for the regional politics (Didenko et al., 2017), and considering that the main socio-economic problems in rural areas include poorly developed social and hard infrastructure, high unemployment level, poorly developed services and low level of education of the local residents (Wojewódzka-Wiewiórska, 2017), it can be argued that the development of rural tourism becomes an essential activity requiring proper attention and management. Rural economies have been first and foremost about natural resource consumption and exploitation; whereas rural tourism development is a rather new phenomenon when compared to traditional rural economic activities (Gartner, 2005).

Kastenholz et al. (2018) emphasize that rural tourism is driven by the search for unique and memorable experiences in particular settings. The study provided by Hjalager, Kwiatkowski, \& Larsen (2018) showed that rural tourism has its basis in a dichotomy between authenticity and modernization. Modernization, in terms of technological development and the expansion of the Internet, has a significant impact on the development in all economic sectors including travel and tourism industry. According to Boyne \& Hall (2004), the Internet has developed rapidly and has become a potentially effective advertising and promotional tool; and for tourism purposes, the web is the most often used research tool by consumers seeking out information and images concerning potential destinations, activities and services. Moreover, according to HidalgoAlcázar, Sicilia, \& De Maya (2015), the sector of rural tourism is one of the most active on the Internet. Melo, Hernández-Maestro, \& Muñoz-Gallego (2017) emphasize that in the tourism industry, most customer feedback and searches for relevant information take place online; therefore, it is important to assess the impact of business online activities and customers' online comments on the choice of tourism object. To be more precise, tourists usually consult user-generated content on the Internet to plan a trip (Hidalgo-Alcázar, Sicilia, \& De Maya, 2015). Therefore, it can be argued that user-generated content in terms of electronicword-of-mouth (eWOM) has a significant impact on consumers' assessment of information provided by a legal entity (in our case, rural tourism homestead).

Maintaining a scientific discussion, the object of this research is Lithuanian rural tourism homestead website quality. Accordingly, the aim is to assess Lithuanian rural tourism homestead website quality. During the research, special emphasis is placed on the impact of eWOM. The scientific problem solved by the research is which factors affect consumer perception of rural homestead website quality? Vassiliadis, Fotiadis, \& Piper (2013) argue that while it is relatively easy to define the quality of a product, the process of defining the quality of a service is a challenge. Primary attempts of assessment of website quality are related to the model provided by Barnes \& Vidgen (2000) called WebQual. Many 
attempts to verify, improve or adapt this model can be found in scientific literature (e.g., Ahmad \& Khan, 2017; Loiacono, Watson, \& Goodhue, 2002, 2007, etc.). Initially, four dimensions were established as the characteristics of website quality: ease of use, experience, information, and communication $\&$ integration. During its modifications, the model was extended to twelve (Loiacono, Watson, \& Goodhue, 2002), or reduced back to four dimensions (Ahmad \& Khan, 2017). Therefore, it can be stated that determinants of website quality are still underassessed.

\section{Materials and Methods}

Achieving to assess the quality of Lithuanian rural homestead websites, the following categories were indicated:

- Overall website quality (Likert scale): useful, reliable, positive, informative;

- Expectations for rural homestead based on the website (Likert scale): reception, atmosphere, nature, overall expectations;

- Looking for eWOM when choosing a rural homestead (Likert scale);

- Relying on eWOM when choosing a rural homestead (Dichotomous question - yes / no);

- Most affective eWOM when choosing a rural homestead (Dichotomous question - positive / negative);

- Importance of factors affecting the rural homestead choice (Likert scale): price, location, convenience, eWOM information, eWOM photos, information on the website, photos on the website.

All of these categories were included in the questionnaire for respondent evaluations with the scales specified. Moreover, question-filter was included in the questionnaire to eliminate the respondents that have never visited a rural homestead. In the end of the questionnaire, two demographic questions, namely, gender and age, were included.
The questionnaire research was conducted on the internet through a specialized survey websites. Totally 298 respondents filled the questionnaire, but 42 of them indicated that have never visited a rural homestead, thus were eliminated from the analysis. Hence, 256 questionnaires (74 per cent of respondents were women; all of the respondents were at the age of $20-35)$ were applied for the analysis of the research results.

Descriptive statistical analysis with IBM SPSS Statistics v.20 and XLSTAT 2014 software packages was done to obtain the results. The application of frequency analysis for respondent evaluations revealed the number of occurrences of each response chosen by the respondents. The two most frequent evaluations revealed the trend of respondents' attitude towards the measured objects.

\section{Results and Discussion}

The overall evaluation of rural homestead website quality contains the evaluation of website usefulness, reliability, the evaluation of whether the website seems to be positive and informative. As it can be seen, 82 per cent of respondents evaluated the rural homestead websites as useful (see Figure 1) - the evaluations of 4 and 5 in the 5-point scale. Only 3 per cent of respondents evaluated rural homestead websites as not useful (the evaluations of 1 and 2 in the 5-point scale). Hence, it could be stated that based on the respondents' evaluations rural homestead websites seem useful to them.

The frequency of the evaluation of rural homestead website reliability is visualized in Figure 2. As it can be seen, 71 per cent of respondents chose the evaluation of 4 or 5 in the 5 -point scale, meaning that they evaluate rural homestead websites as reliable. Only 6 per cent of respondents believe that rural homestead websites are not reliable (the evaluations of 1 and 2 in the scale of 5).

The frequency of the evaluation of rural homestead websites as positive is visualized in Figure 3. As it can

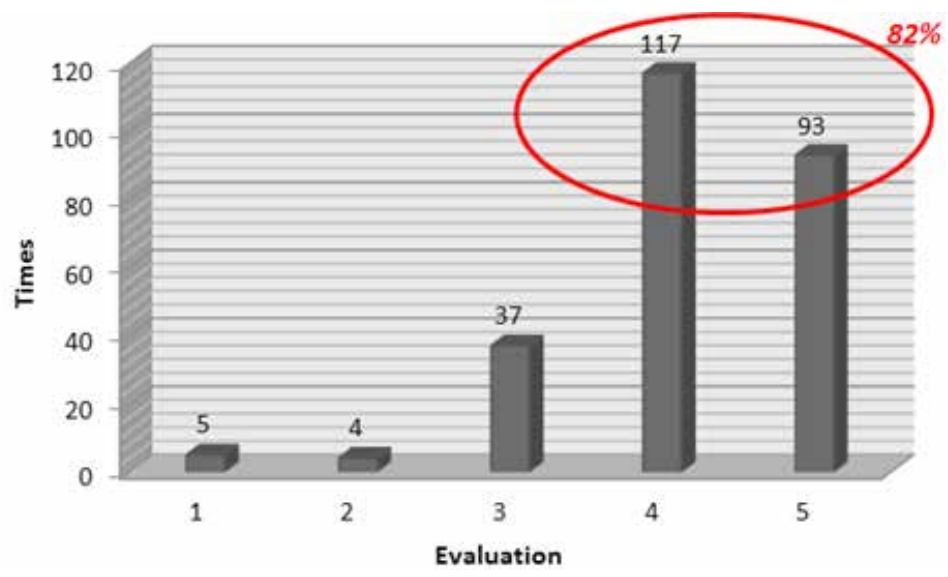

Figure 1. Frequency of the evaluation of website usefulness. 


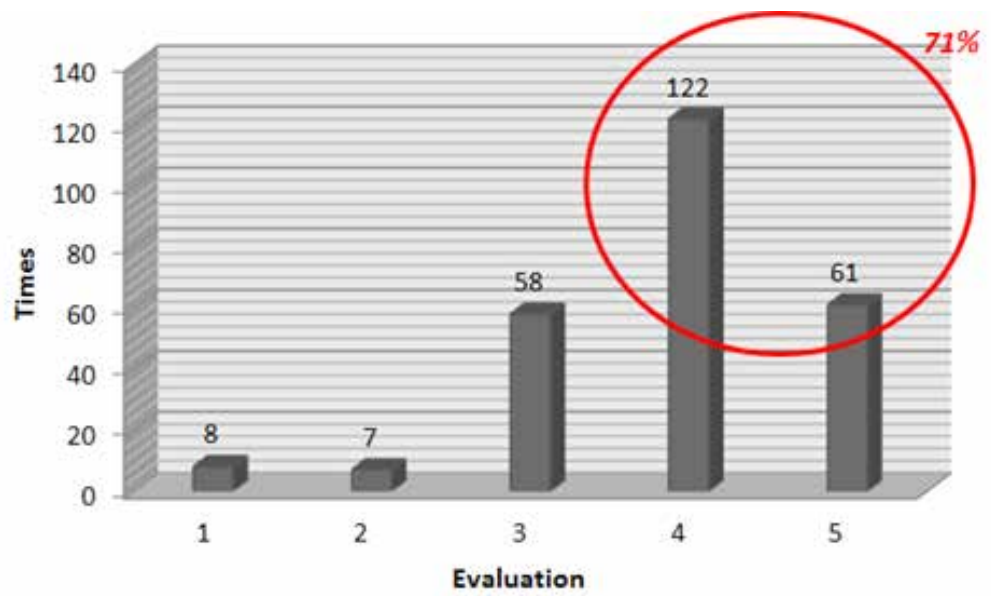

Figure 2. Frequency of the evaluation of website reliability.

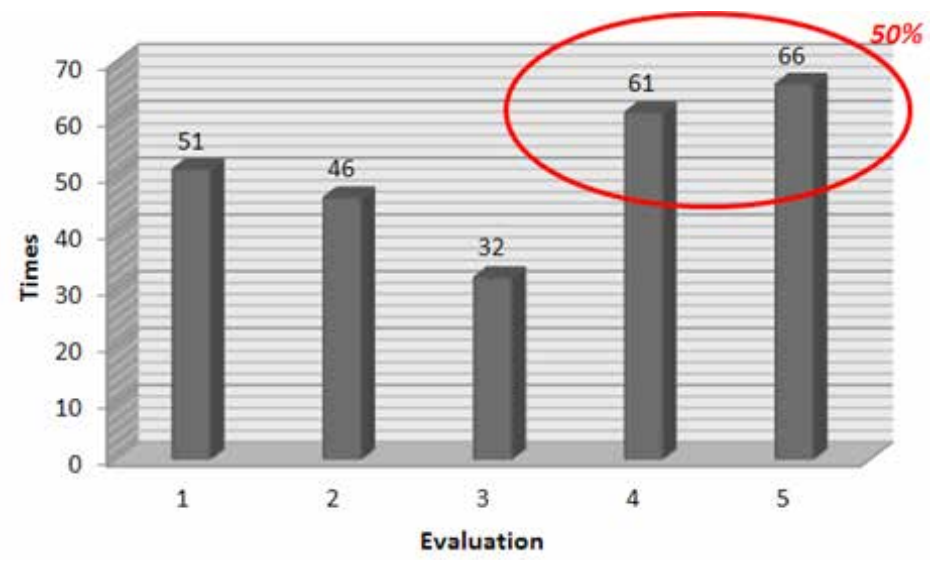

Figure 3. Frequency of the evaluation that website is positive.

be seen, 50 per cent of respondents chose the evaluation of 4 or 5 , meaning that they evaluate rural homestead websites as positive. Nevertheless, 38 per cent of respondents evaluated rural homestead websites as negative (the evaluations of 1 and 2). Hence, unlike the evaluation of rural homestead website usefulness and reliability, the evaluation of rural homestead websites as positive has a greater dissemination. Therefore, it could be stated that the positivism of rural homestead websites has management gaps.

The frequency of the evaluation of rural homestead websites as informative is visualized in Figure 4.

As it can be seen, most of the respondents (55 per cent) chose the evaluation of 1 or 5 , meaning that they evaluate rural homestead websites as very informative or very uninformative. Totally, 44

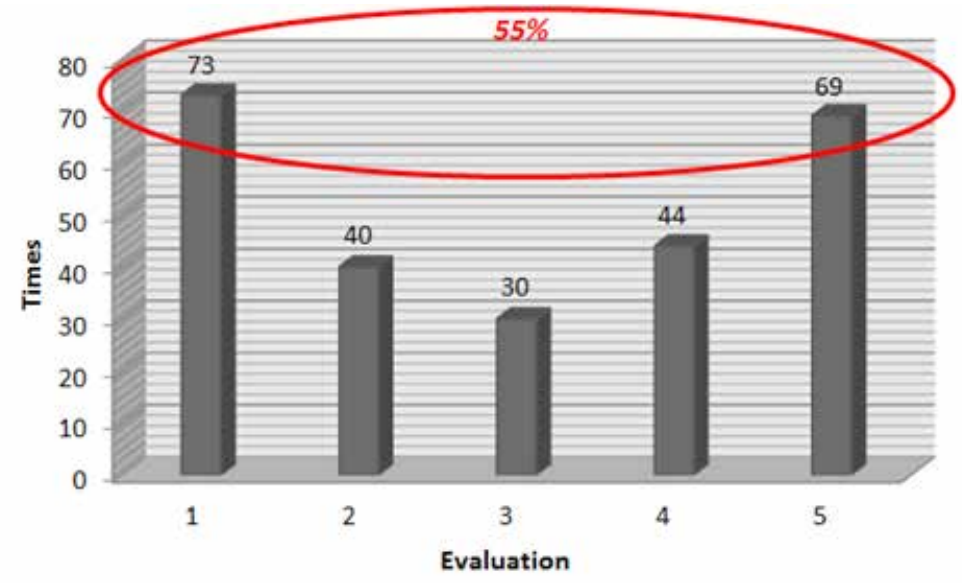

Figure 4. Frequency of the evaluation that website is informative. 


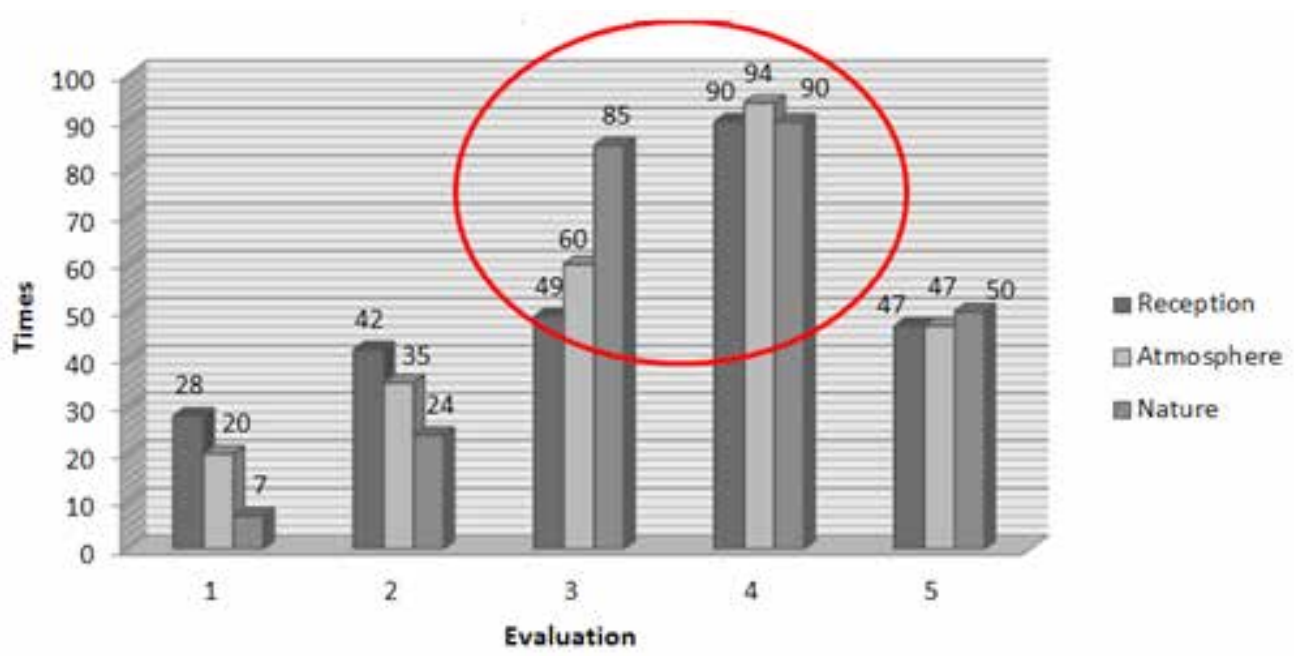

Figure 5. Frequency of the evaluation of the expectations for reception, atmosphere, and nature.

per cent of respondents chose the evaluation of 4 or 5 , meaning that the websites are informative, and 44 per cent of respondents chose the evaluation of 1 or 2 , meaning that the websites are not informative. Such dissemination of the results signifies that the amount of information on the rural homestead websites can be sufficient, but it has to be managed in another way. Hence, the assumption could be made that consumers do not find the information on the rural homestead websites easy or in the convenient place of the website.

The frequency of the evaluation of expectations for rural homestead reception, atmosphere, and nature after visiting their websites is provided in Figure 5. As it can be seen, respondents have average and above average expectations for reception (54 per cent), atmosphere ( 60 per cent), and nature ( 68 per cent) for rural homesteads after visiting their websites. The assumption could be made that rural homestead websites do not provoke high expectations with the information and visuals provided regarding reception, atmosphere, and nature. The question rises whether this is done on purpose in order to raise satisfaction (if the reception, atmosphere, and nature exceed expectations, the level of satisfaction rises) or this is done not on purpose. In the first case, if this is done on purpose, there is a threat that low expectations may cause negative influence on the behaviour (customers will not come to the specific homestead due to the low expectations for the reception, atmosphere, and nature). In the second case, if this is done not on purpose, the information and visuals regarding reception, atmosphere, and nature on the websites must be managed properly in order to raise expectations.

Despite average expectations for rural homestead reception, atmosphere, and nature, overall expectations for rural homesteads after visiting their websites are high (see Figure 6). As it can be seen, 69 per cent of respondents evaluate their overall expectations with 4 or 5 in the scale of 5 , meaning that they evaluate expectations for rural homesteads based on their websites as above average / high. Hence, based on the analysis of the research results, it could be stated that

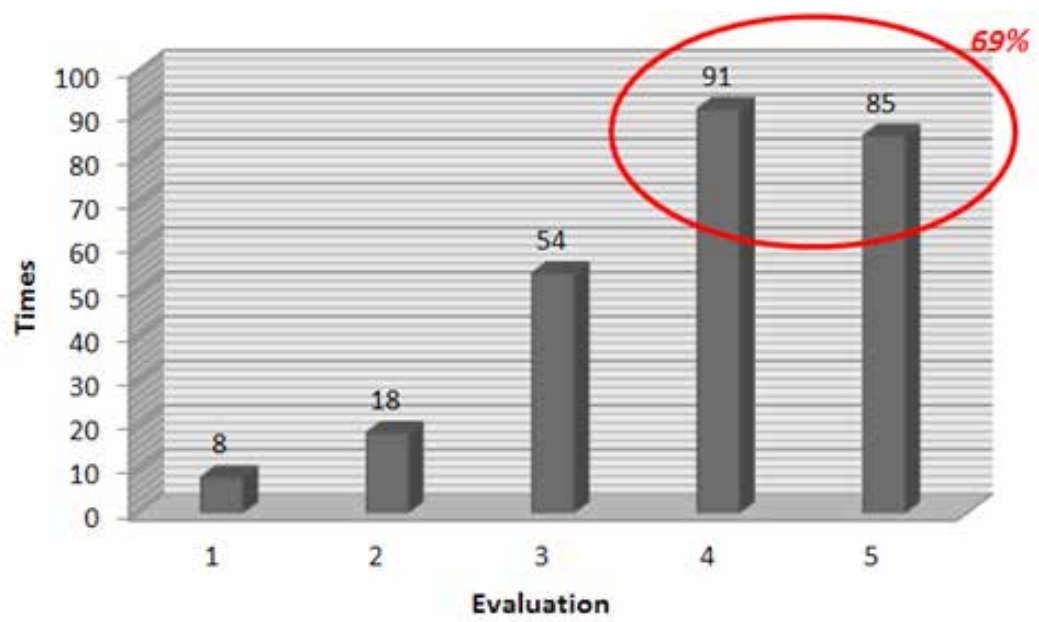

Figure 6. Frequency of the evaluation of the overall expectations. 


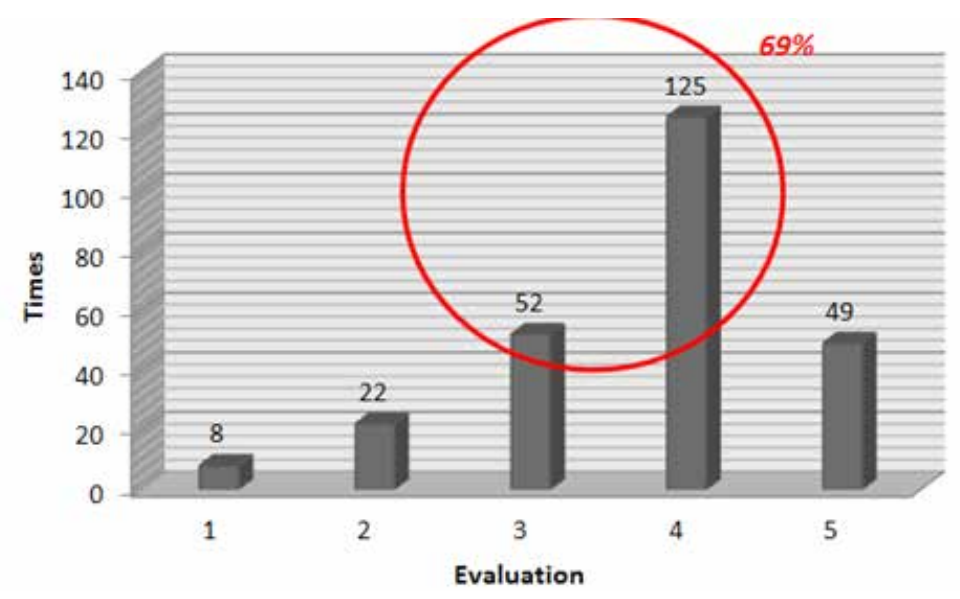

Figure 7. Frequency of the evaluation of looking for eWOM.
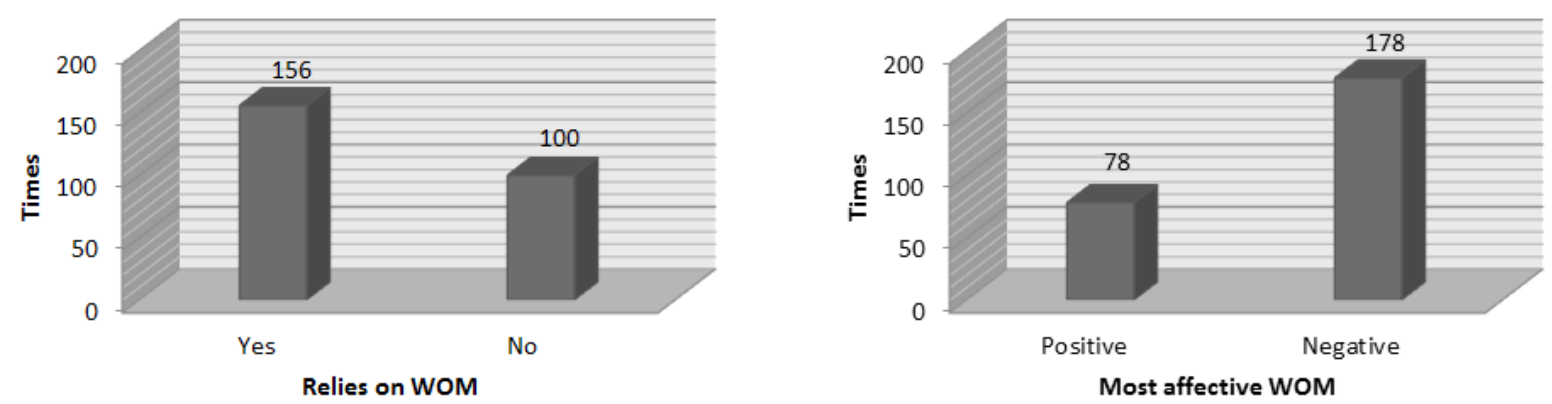

Figure 8. Frequency of the evaluation of relying on eWOM and most affective eWOM.

rural homestead websites provoke high expectations except for reception, atmosphere, and nature.

The frequency of the evaluation of looking for eWOM on the Internet regarding rural homesteads is visualized in Figure 4. As it can be seen, the two most frequent evaluations are 3 and 4 (69 per cent of respondents); hence it could be stated that respondents are looking for eWOM regarding rural homesteads, but not always and / or not widely through the Internet.

The frequency of the evaluation of relying on eWOM and the most affective eWOM is provided in Figure 8 below. As it can be seen, 60 per cent of the respondents rely on eWOM when choosing a rural homestead. Moreover, for the 70 per cent of respondents negative eWOM are the most affective; hence, it could be stated that negative eWOM has higher impact on the choice of the rural homestead when compared to the positive eWOM. Based on the results, the assumption could be made that consumers are looking for negative eWOM regarding a specific rural homestead and if there is none, such rural homestead becomes the choice under consideration, but if negative eWOM are found, they rely on the eWOM and do not consider this rural homestead. To manage such situation, the recommendation is to contain the eWOM part on the rural homestead's website in order to reply to the negative eWOM and lower the possibility that consumers will search for the negative eWOM widely through the Internet.

The frequency of the evaluation of the importance of price, location, and convenience provided on the website when choosing a rural homestead is shown in Figure 9. As it can be seen, all of these three factors are very important when choosing a rural homestead and should be provided on the rural homesteads' websites. Price is very important (evaluations of 4 and 5) for 79 per cent of respondents, location is very important (evaluations of 4 and 5) for 88 per cent of respondents, and convenience is very important (evaluations of 4 and 5) for 77 per cent of respondents. It could be stated that the absence of the description of these factors on the rural homestead's website can influence the decision not to consider such a homestead for the visit.

The frequency of the evaluation of the importance of eWOM information and photos compared to the information and photos provided on the website when choosing the rural homestead for the visit is provided in Figure 10. As it can be seen, eWOM information and photos, as well as information and photos provided on the rural homestead websites are very important (the most frequent evaluations are 4 and 5 in the 5-point scale). eWOM information is evaluated as important / very important by 83 per cent of the respondents; 


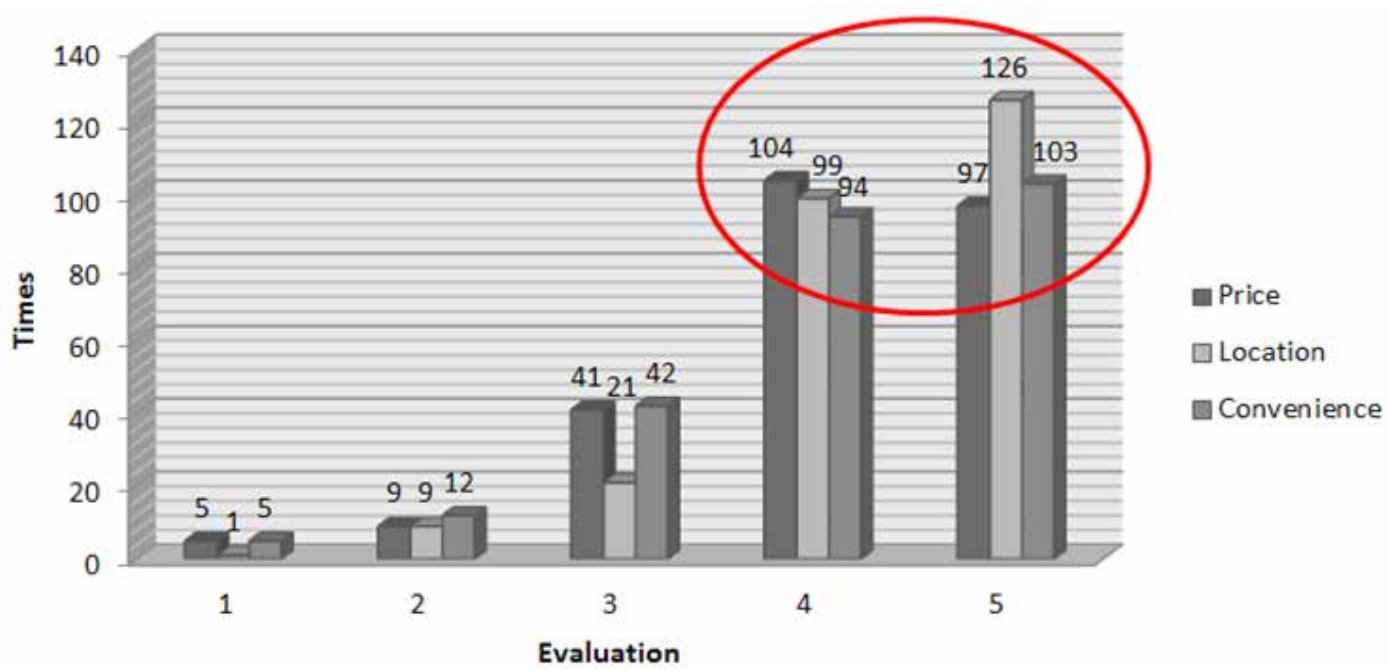

Figure 9. Frequency of the evaluation of the importance of price, location, and convenience.

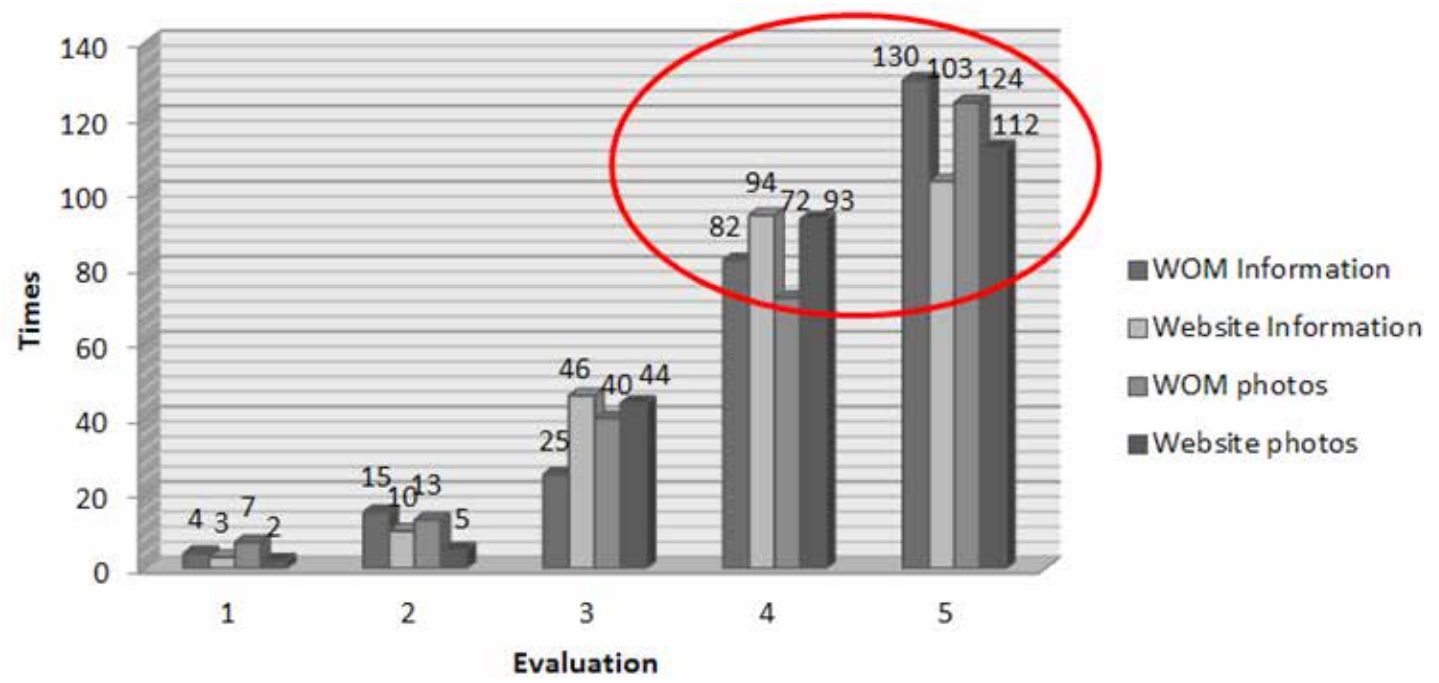

Figure 10. Frequency of the evaluation of the importance of eWOM information and photos compared to the information and photos provided on the website.

information provided on the rural homestead websites is evaluated as important / very important by 77 per cent of the respondents. eWOM photos are evaluated as important / very important by 77 per cent of the respondents; photos provided on the rural homestead websites are evaluated as important / very important by 80 per cent of the respondents. Consequently, most of the respondents evaluated eWOM information and photos provided on the rural homestead websites as very important. Hence, not only the information provided on the rural homestead websites, but photos as well have to be managed properly in order to maintain high website quality. Moreover, the results of the evaluation of the importance of eWOM information and photos support the recommendation to contain the eWOM part on the rural homestead websites.

The research results indicated the main problems related to the quality of Lithuanian rural homestead websites. Knowing the problems, the solutions for their management can be elaborated.

\section{Conclusions}

Based on the analysis of the research results, it could be stated that in order to achieve high Lithuanian rural homestead website quality, the management of the websites is necessary. Firstly, the information on the websites has to be easy to find, clear, and consistent. The information has to contain the aspects of price, location, and convenience of the homestead. Secondly, the information on the website has to be complemented by photos that substantiate the information. Thirdly, the information and photos regarding reception, atmosphere, and nature provided on the websites has to be managed properly in order to raise current expectations. Finally, the recommendation is to contain the eWOM part on the rural homestead websites in order to reply to 
the negative eWOM and lower the possibility that consumers will search for the negative eWOM widely on the Internet. The management of these factors can enhance the possibility to maintain high quality website that influences consumers' intention to visit the homestead.

\section{References}

1. Ahmad, A., \& Khan, M.N. (2017). Developing a Website Service Quality Scale: A Confirmatory Factor AnalyticApproach.Journal OfInternet Commerce, 16(1), 104-126.DOI: 10.1080/15332861.2017.1283927.

2. Barnes, S.J., \& Vidgen, R.T. (2000). WebQual: An Exploration of Web Site Quality. Proceedings of the Eighth European Conference on Information Systems, July 3-5, 2000, (pp. 298-305). Austria, Vienna.

3. Boyne, S., \& Hall, D. (2004). Place Promotion through Food and Tourism: Rural Branding and the Role of Websites. Place Branding, 1(1), 80-92.

4. Csaholczi, A., Mirea, A., Petroman, C., \& Marin, D. (2017). Study Regarding the Impact of Farm Tourism and Agrotourism on Rural Area. Agricultural Management / Lucrari Stiintifice Seria I, Management Agricol, 19(3), 125-128.

5. Didenko, N., Skripnuk, D., Mirolyubova, O., \& Radion, M. (2017). Analysis of Rural Areas Development of the Region Using the ADL-Model. Research for Rural Development, 2, 142-147. DOI: 10.22616/ rrd.23.2017.061.

6. Gartner, W.C. (2005). A Perspective on Rural Tourism Development. The Journal of Regional Analysis and Policy, 35(1), 33-42.

7. Ghadban, S., Shames, M., Abou Arrage, J., \& Abou Fayyad, A. (2017). Rural Tourism in Lebanon: What Does the Market Reveal?. Revue Management Et Avenir, 96, 165-185.

8. Hidalgo-Alcázar, C., Sicilia, M., \& De Maya, S.R. (2015). La Imagen de un Producto Turístico Rural a través del Acceso al Contenido Generado por otros Usuarios en Internet: Diferencias por Género. Journal Of Technology Management \& Innovation, 10(3), 75-84.

9. Hjalager, A., Kwiatkowski, G., \& Larsen, M.Ø. (2018). Innovation Gaps in Scandinavian Rural Tourism. Scandinavian Journal Of Hospitality \& Tourism, 18(1), 1-17. DOI: 10.1080/15022250.2017.1287002.

10. Kastenholz, E., Carneiro, M.J., Marques, C.P., \& Loureiro, S.C. (2018). The Dimensions of Rural Tourism Experience: Impacts on Arousal, Memory, and Satisfaction. Journal Of Travel \& Tourism Marketing, 35(2), 189-201. DOI: 10.1080/10548408.2017.1350617.

11. Loiacono, E.T., Watson, R.T., \& Goodhue, D.L. (2002). WEBQUAL: A Measure of Website Quality. AMA Winter Educators' Conference Proceedings, 13, 432-438.

12. Loiacono, E.T., Watson, R.T., \& Goodhue, D.L. (2007). WebQual: An Instrument for Consumer Evaluation of Web Sites. International Journal Of Electronic Commerce, 11(3), 51-87. DOI: 10.2753/JEC1086441511030 .

13. Melo, J.D.V.T.A., Hernández-Maestro, R.M., \& Muñoz-Gallego, P.A. (2017). Service Quality Perceptions, Online Visibility, and Business Performance in Rural Lodging Establishments. Journal Of Travel Research, 56(2), 250-262. DOI: 10.1177/0047287516635822.

14. Patil, S.S., \& Mulani, M.U. (2017). Problems and Prospects of Rural Tourism: The Case of 'B' \& 'C' Category Pilgrimage Places in Pune Area. Journal Of Commerce \& Management Thought, 8(2), 361-371. DOI: 10.5958/0976-478X.2017.00021.0.

15. Vassiliadis, Ch.A., Fotiadis, A., \& Piper, L.A. (2013). Analysis of Rural Tourism Websites: the Case of Central Macedonia. Tourismos: An International Multidisciplinary Journal of Tourism. 8(1), 247-263.

16. Wojewódzka-Wiewiórska, A. (2017). The Importance of the LEADER Programme 2007-2013 in the Rural Areas Development in Poland. Research for Rural Development, 2, 97-103. DOI: 10.22616/ rrd.23.2017.055. 